\title{
Four Studies of University Library Problems
}

Dr. Swank is Chairman, University Libraries Section, ACRL.

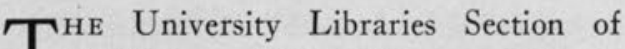
1 ACRL has established four special committees to study problems pertaining to technical scientific reports, undergraduate and underclass libraries, decentralization of cataloging, and in-service training. The chairmen of the committees will attend the section meeting at the midwinter conference of the ALA at Chicago, and the entire program will be devoted to discussion of their projects. The present announcement is intended to inform section members about the projects, to stimulate their thinking, and to invite their participation both by attendance at the midwinter meeting and by direct correspondence with the committee chairmen. Reports of the projects will be published later.

The chairmen of the special committees have hastily prepared the following preliminary statements by way of introduction to the studies which are about to be undertaken. The necessity of submitting early copy for inclusion in this issue of College and Research Libraries precluded any systematic presentation at this time. By conference time, however, the projects will probably have been formulated more carefully. Meanwhile, comments and suggestions from interested librarians will be welcomed by the committee chairmen.

Since the membership of these special committees has not yet been completed, an announcement of the names of all participants will have to be postponed until the midwinter meeting.
Committee on Technical Reports-Mortimer Taube, Chairman ${ }^{1}$

A new and important body of technical literature is arising parallel to an existing body in the fields of science and engineering. This new literature is largely separate because of mode of origin and security restrictions, and much of it has not yet been absorbed into university libraries. What is this literature? What brought it about? Where does it come from? How is it distributed? Where does it go and where is it kept? What limitations are placed on its use? In general terms, the committee will undertake to describe the facts of the present situation and to recommend what university libraries and other agencies should be doing with these materials.

Committee on Undergraduate and Underclass Libraries-William S. Dix, Chairman

The excellence of a university libiary has traditionally been measured by the strength of its research collection. It seems quite possible that emphasis upon the acquisition of materials necessary for research has tended to neglect of the needs of the undergraduate. The small college library, realistically aware that it cannot attempt to provide research material, in concentrating upon the best possible integration of the library with the academic program of its institution may thus be fulfilling its responsibilities to the undergraduate much more successfully than the more renowned library of the larger university. What is the ideal

1 The following statement was written for $\mathrm{Mr}$. Taube by $\mathrm{Mr}$. Swank. 
arrangement for the undergraduate library in a university? Or, short of the ideal, how may the educational needs of the underclass student be met in the university library system?

Two examples may serve to indicate different approaches to this problem. The construction of the Lamont Library at Harvard represents one recent attempt to meet the special needs of the undergraduate. Here a separate building with a carefully selected special collection is provided. The construction of the Fondren Library at the Rice Institute at about the same time represents an entirely different approach to the problem, dictated of course by entirely different local circumstances. At Rice all library holdings have been housed in a single building and no distinction whatever is made between undergraduate and research collections. Both of these decisions were made deliberately after considerable study of the needs of the different institutions.

These are both rather extreme examples, and it is obvious that the relationship between the college library and the university library must be worked out in terms of the unique needs of each institution. However, in spite of the special nature of each problem, a study of existing practices and the experience of a number of libraries should provide certain common denominators of value. Since there obviously exist solutions to the problems at many points on the spectrum between these two examples, there arises immediately a host of special problems ranging through all levels of library operation. The physical housing of the library, the relative proportion of the total budget allocated for undergraduate needs, the content of the college library wherever any segregation is made, the kind of cataloging most appropriate to the undergraduate, even circulation rules may be factors which are relevant to educational function of the college library in the University.
These are the matters of which the committee proposes to make a brief preliminary study.

\section{Committee on Decentralization of Catalog- ing-Harry Dewey, Chairman}

A number of students have compared the revelatory capacity of the card catalog with that of printed bibliographies. These investigations have shown that the analytical powers of the printed bibliographies render them generally superior to the dictionary catalog. However, the investigators assume, in every case, that the ultimate bibliographical units (the series, in the case of an analytical reference, for example) are always in the library and represented in the card catalog. This is taken for granted because of the assumption that cataloging, except for a few comparatively unimportant exceptions, is centralized.

However, there appear to be large classes of materials (ultimate bibliographical units) that are not processed by the main catalog department and are not represented in many present-day card catalogs. Examples of these are government documents, technical reports, reprint collections, manuscripts, pamphlet files, periodicals, law books, rare books, college bulletins, and films. Other classes may be processed in part by the main catalog department and finished by other departments. For example, descriptive cataloging of materials in subject departments may be done centrally, while special subject indexes are prepared in the departments. Still other materials, because of their special subject nature, rather than format, may be cataloged only in special or departmental collections, on the theory that those who need them or want them will go directly to the departmental catalog. It appears possible that cataloging, especially in the larger university libraries, may not be as centralized as generally assumed.

This committee proposes to study the 
present extent of decentralization of cataloging, defined broadly as the organization of materials by any method. Specifically, the committee intends to appraise, delimit and outline the three areas of investigation described below, and to launch some actual investigation. The potentialities and program of the committee should benefit from impetus and direction given by the forthcoming midwinter conference discussions.

First, what organized collections, or kinds of collections, are not at present processed by the main library catalog department or represented in the main card catalog? How many pieces do they contain, and what proportion are they of the entire resources of the library? Who organizes these so-called "uncataloged" materials for use? Where are the records located and what relationship, if any, do they bear to the main card catalog?

Second, what collections, having been conventionally cataloged in part or in full by the main catalog department, and conventionally represented in the main card catalog, are then subjected by other departments to supplementary work and why? Where are the records located and what relationship do they bear to the maip card catalog?

Third, what collections are cataloged conventionally, but not by the central catalog department? To what extent are cards supplied for the main catalog? A significant study has already been made in this area. ${ }^{2}$ This study, however, intentionally omitted collections not attached to departments of instruction or schools or colleges of a university, collections for which catalog and shelflist cards were omitted, and collections administered separately or independently of the main library administration. It did not include any of the largest university librar-

\footnotetext{
2 Janet Dickson, "Centralized Cataloging in College and University Libraries." Master's Essay. School of Library Service, Columbia University, 1946. Abridged in College and Research Libraries, 8:225-31, July, 1947.
}

ies. The author of this study suggested that some of these areas be explored.

The methods to be employed in making such studies are worthy of consideration just as serious as that given to the subjects of the studies. Should the studies be primarily statistical? Should the emphasis be on quantitative analysis whereby valid generalizations may be deduced, or should case studies be made of a small number of institutions? By that method, types and patterns of behavior could be described and compared, without statistical generalization. Processes described, and the reasons underlying specific situations could be introduced.

The committee is particularly interested in learning about the needs of librarians for the suggested types of studies and in knowing how the results would be put to use.

\section{Committee on In-Service Training-Elmer Grieder, Chairman}

It is generally accepted that a distinction ought to be made between professional and non-professional library employees, and that competent non-professionals should be given as many routine responsibilities as possible in order to free career librarians for genuinely professional work. The clearest differentiation between staff members is based on the completion of graduate library training. Those who have it are called professionals; others, except for a few who reach major positions of authority and responsibility, are not.

As regards duties, no such convenient, if frequently misleading, criterion exists. Certain tasks are obviously non-professional; as responsibilities increase the demarcation becomes less clear, until a level is reached at which quasi-professional duties may be handed over to intelligent and experienced non-professionals.

A corps of well trained and libraryminded non-professionals is recognized as an invaluable asset to every library of any size. 
This committee expects to study the training which libraries can provide to improve the competence of this group and to prepare its members for more responsible and exacting duties. It will be necessary also to examine the nature and scope of the duties which can appropriately be assigned to them, their status in the library personnel program and their relationship to the professional staff.
There appears to be little formal and systematic training for non-professionals, though undoubtedly much is done on an informal and rather haphazard basis. The committee hopes to obtain information on any organized programs which may be in existence in university libraries. Communications from librarians with any pertinent experience or ideas on the subject will be very welcome.

\section{League of Nations Documents and Publications Comparable With or Continued in United Nations Publications}

\section{(Continued from page 52)}

Wilson Foundation this comprehensive card Catalog and its collection of League of Nations documents.

Catalog cards are now available from the Library of Congress for some serials and printed publications of the United Nations.

\section{League Publications on Sale}

The great majority of the publications of the League of Nations are still in print and are available through the United Nations. Catalogs covering the period 1920-1946 may be obtained by writing to the Sales and Circulation Section, United Nations, New York. The mimeographed documents of the League of Nations were not placed on sale. The unrestricted mimeographed documents of the United Nations, however, may be obtained on an annual global subscription through the Sales and Circulation Section. The United Nations publications are available in 58 countries through 63 official sales agents or cooperating bookshops. The official sales agent in the United States is the International Documents Service, Columbia University Press, 2960 Broadway, New York 27, N.Y.

\section{Studies and Reports, or Monographs}

The studies and reports prepared by the Secretariat of the United Nations cover to a large extent the same subject fields, or a development of them, as those issued under the League of Nations imprint.

In addition to the serial publications discussed above, the following types of printed publications have been made available in League of Nations documentation: proceed- ings of international conferences including conventions, agreements, etc.; reports on a wide variety of topics submitted to these conferences, or to Member States for comment and observations, and special studies or inquiries requested by the Assembly and Council of the League of Nations. In view of the fact that space does not permit a more detailed comparison by title of these valuable contributions of the League of Nations to an understanding of international problems with those issued by the United Nations, it may be stated briefly that the counterpart of such studies or monographs can readily be found in the catalogs issued by the United Nations Department of Public Information describing publications offered for sale, 1945-48-49-50.

It must also be noted that many of the activities and publications of the League of $\mathrm{Nations}$ are not continued by the United $\mathrm{Na}$ tions but have been assumed by the Specialized Agencies, which make annual reports to the Economic and Social Council on their work. These specialized agencies cover such fields as international labor relations, food and agriculture, educational, scientific and cultural problems, civil aviation, monetary, economic reconstruction and development questions, postal communications, telecommunications, refugee and displaced persons, international trade, meteorology, and world health.

Each of these agencies issues its own publications and no attempt is made in this paper to describe the continuance by them of former League periodicals or documents series, or to trace their ancestors in the League of Nations publications. 